\title{
ANARCHISTYCZNA TEORIA REWOLUCJI NAUKOWYCH
}

Jednym z elementarnych złudzeń towarzyszących rozwojowi nauki jest oczekiwanie na przełomowe odkrycia, które doprowadziłyby do uporządkowania naszej wiedzy oraz do usunięcia wszystkich interpretacyjnych niejasności. Przejawy podobnego optymizmu poznawczego można znaleźć zarówno na płaszczyźnie badań naukowych, jak i w perspektywach refleksji metanaukowej. Pierwsze z nich występują obecnie sporadycznie, gdyż załamanie się mechanicyzmu oraz powstanie teorii względności i mechaniki kwantowej doprowadziło do rezygnacji z oczekiwań na koniec fizyki zapowiadany w czasach studiów Plancka i Einsteina. Szczególny rozwój refleksji metanaukowej prowadzi natomiast do przeniesienia $w$ tę dziedzinę optymistycznych oczekiwań na jednoznaczne określenie mechanizmów rozwoju nauki. Następstwem tego są wielorakie próby określenia struktury rewolucji naukowych. Niezależnie od tego, czy w próbach tych akcentuje się rolę racjonalnych składowych nauki czy też doniosłość czynników psycho-społecznych, są one inspirowane przekonaniem, iż możliwe jest odkrycie mechanizmów kierujących wszystkimi rewolucjami naukowymi.

W artykule tym chcę wykazać, iż poszukiwanie jednej teorii wszystkich rewolucji naukowych stanowi wyraz narzucania struktury nomologicznej procesom, których adekwatna charakterystyka możliwa jest jedynie w perspektywach nauk idiograficznych. Na przekór dążeniom autorów podejmujących Kuhnowską tezę o występowaniu jednolitej socjologicznej struktury wszystkich rewolucji naukowych, formułuję tezę, iż w okresie tych rewolucji podstawową zasadą rozwoju jest liberalna reguła Feyerabenda: anything goes. Podobny liberalizm metodologiczny nie jest przejawem metanaukowej fantazji, lecz ma mocne konfirmacje empiryczne ze strony danych dotyczących przebiegu przeszłych rewolucji naukowych. Jego logicznym następstwem jest proponowana przeze mnie anarchistyczna teoria rewolucji naukowych, która głosi, iż poszczególne rewolucje rządzą się odmiennymi prawami i dlatego niemożliwe jest określenie jednolitych uniwersalnych reguł zmian paradygmatów. 
Rozwój analiz z zakresu filozofii nauki doprowadził do zarzucenia skrajnych stanowisk, w których proces postępu wiedzy usiłowano tłumaczyć przez odwołanie się wyłącznie do jednego typu uwarunkowań empirycznych, racjonalnych lub psycho-społecznych. W realistycznej filozofii nauki trzeba uwzględnić rolę wszystkich tych czyników. Pominięcie któregoś z nich może prowadzić do wyidealizowanych i uproszczonych koncepcji procesu rozwoju nauki. W wyniku takich uproszczeń historia nauki staje się jedynie filozofią nauki realizowaną przez przykłady. Podobne zacieranie epistemologicznych różnic między zdaniami nomologicznymi i idiograficznymi jest jednak przedsięwzięciem całkowicie bezpodstawnym. Poszukiwanie niezależnych od czasu mechanizmów rozwoju nauki staje się ekspresją neo-heglowskich prób racjonalizacji historii. Interpretowanie rewolucji Einsteinowskiej przy pomocy tych samych schematów interpretacyjnych, które doprowadziły do rewolucji Newtonowskiej jest przedsięwzięciem równie dowolnym, jak próby interpretacji końca Hohenzollernów przy pomocy struktur charakteryzujących schyłek Piastów czy Romanowów.

Quasi-historyczna próba racjonalnego określenia porządku sukcesji poszczególnych władców byłaby niewątpliwie przejawem optymizmu epistemologicznego jej autorów, ale jej zgodność z faktyczną sukcesją władców przemawiałaby w wysokim stopniu za tym, iż interpretujący historiozofowie stosowali nie predykcje, lecz retrodykcje. W przedstawianych obecnie teoriach rewolucji naukowych szczególną rolę pełnią właśnie retrodykcje. Dlatego też teorie te są tak bardzo zróżnicowane, gdyż przy wyjaśnieniach ex post zawsze istnieją szerokie możliwości określania różnorodnych zbiorów faktów uważanych za reprezentatywne. Historia nauki obciążona jest filozofią nauki i w konsekwencji wszelkie charakterystyki przebiegu rewolucji naukowych są również uzależnione od przyjmowanych założeń metodologicznych. Zależności te tworzą swoiste błędne koło, gdyż potwierdzenia dla słuszności poszczególnych metodologii poszukuje się $\mathrm{w}$ historii nauki, zaś obraz rozwoju nauki uzależniony jest $\mathrm{w}$ dużym stopniu od przyjmowanych założeń metanaukowych. Jest oczywiste, że odmienne metodologie nie prowadzą do całkowicie rozłącznych opisów historiograficznych, niemniej zróżnicowanie opinii $\mathrm{w}$ tej dziedzinie przejawia się już przy próbach odpowiedzi na pytanie, ile rewolucji naukowych można wyodrębnić $\mathrm{w}$ dotychczasowym procesie rozwoju wiedzy. Gdyby dwadzieścia kilka wieków przez T. Kuhnem któryś ze starożytnych Rzymian napisał dzieło De structura revolutionum in scientia, jego opis przejścia od nauki egipsko-babilońskiej do nauki greckiej mógłby uwzg'ędniać elementy całkiem różne od tych, które uważane są za istot- 
ne w perspektywach współczesnych teorii rewolucyjnych. Z perspektyw wiedzy 50 roku przed Chrystusem byłyby podstawy do twierdzenia, iż rewolucja prowadząca do przyjęcia greckich wzorców nauki polegała na wprowadzeniu czynnika teoretycznego na miejsce wcześniejszych czysto pragmatycznych zagadnień oraz na wypracowaniu zbioru twierdzeń o wysokim stopniu spójności i abstrakcyjności. Gdyby cechy te uznać jednak za konieczne następstwa każdej rewolucji, wówczas program badawczy Kopernika-Galileusza trzeba by uznać za antyrewolucję, gdyż prowadził on do następstw przeciwnych niż wymienione. Panująca przed powstaniem tego programu fizyka Arystotelesowska miała wyższy od fizyki współczesnej stopień abstrakcji; w wyniku jej połączenia z metafizyką ukazywała ona także bardziej spójny całościowy obraz świata ${ }^{1}$ i miała mniejsze zastosowania praktyczne niż związana $\mathrm{z}$ obserwacjami i nową aparaturą technologiczną fizyka Galileusza. O tym jak wielką idealizację stanowią wypowiedzi o przesunięciu paradygmatów świadczy $\mathrm{m}$. in. to, że w objętych statystyką 2330 artykułach naukowych powstałych w okresie lat 1543-1687 tylko 7,7\% \% autorów wypowiadało się jednoznacznie za programem Kopernika-Galileusza ${ }^{2}$. Zamiast o przesunięci u paradyg mató należałoby raczej mówić o czołganiu się wielu mik r o-paradyg m a tó w, jako że obok astronomii, w której poważną alternatywną propozycję przedstawił Tycho Brahe, w dziedzinie chemii czy biologii podtrzymywano wzorce interpretacji, na które nie miały praktycznie żadnego wpływu interpretacje Galileusza. Uwzględniając to należałoby większą wagę zwrócić na proces mikro-rewolucji naukowych prowadzących do nowych programów badawczych i uwzględniających epistemologiczną specyfikę poszczególnych dyscylin. Znamienne jest, iż w rewolucji metanaukowej, jaka miała miejsce w naszym stuleciu, rewolucja w dziedzinie metalogiki miała całkowicie odmienny przebieg niż rewolucja w epistemologii nauk przyrodniczych. Przełomowe odkrycia matematyczne nie były poprzedzone przez wzrost liczby anomalii, lecz były następstwem prób określenia podstaw matematyki. Nie można również sugerować, by po rewolucji tej uległy istotnym zmianom podstawowe pojęcia liczby całkowitej czy zbioru, jakkolwiek nie można również zaprzeczyć, iż w niektórych działach matematyki dokonały się zasadnicze

1 Wiele zagadnień kosmologicznych i fizykalnych, które pozostawały bez odpowiedzi w teoriach Kopernika czy Galileusza otrzymywało szczegółowe odpowiedzi na gruncie fizyki Arystotelesa. Fizyka ta nie tylko opisywała struktury kosmiczne, lecz także wskazywała ich uwarunkowania; nie tylko charakteryzowała przebieg ruchów fizycznych, lecz również tłumaczyła przyczyny ich występowania. Por. S. Toulmin, Human Understanding. The Collective Use and Evolution of Concepts, Princeton 1972.

2 Zab. M. Polanyi, Personal Knowledge, Towards a Post-Critical Philosophy, London 1962, s. 147 przyp. 2. 
przekształcenia treści pojęć (np. pojęcie liczb nieskończenie małych w analizie nie-standardowej).

Podejmowane w ostatnim okresie próby wypracowania jednolitej teorii rewolucji naukowych są właściwie próbami ukazania mechanizmów rewolucji fizykalnych. Ukazują one $\mathrm{z}$ dobrym przybliżeniem strukturę rewolucji Einsteinowskiej i Newtonowskiej, kiedy to istotne przemiany $\mathrm{w}$ naukowym obrazie świata dokonały się dzięki rozwojowi fizyki we współczesnym rozumieniu tego terminu. Przejawem interpretacyjnego optymizmu byłoby jednak podejmowanie prób określania charakteru przyszłych rewolucji naukowych na podstawie doświadczeń związanych z dwiema wymienionymi rewolucjami. Nawet jeśli nie podziela się tez o przyszłym końcu fizyki, nie ma merytorycznych powodów by przypuszczać, że przyszłe głębokie przemiany w teoretycznej interpretacji świata muszą łączyć się z odkryciami w dziedzinie fizyki. Nie można wykluczyć możliwości, że przełomowe odkrycia przyszłości dokonają się w dziedzinie biologii, psychologii czy aksjologii. W odniesieniu do tych dziedzin próba aplikacji niektórych pojęć wypracowanych w dotychczasowych analizach rewolucji naukowych wydaje się bezsensowna. Co np. można by uznać obecnie za oznakę anomalii w psychologii, aksjologii czy etyce? Jeśliby wszystkie zagadnienia niewyjaśnione w tych dziedzinach uznać za anomalie, wówczas wymienione dyscypliny bylyby $w$ obecnym stadium rozwoju przede wszystkim zbiorem anomalii.

Wśród prób wypracowania jednolitej teorii wszystkich rewolucji naukowych należy wyróżnić dwa zasadniczo odmienne typy interpretacji. W pierwszym z nich prawa rewolucji określane są przez socjologię nauki, $\mathrm{w}$ drugim są one przejawem wewnętrznej racjonalności nauki. W socjologicznym ujęciu elityzmu ${ }^{3}$, zachowanie społeczności badaczy jest bardziej doniosłe niż obiektywna treściowa zawartość teorii naukowych; prawa psychologii tłumu i uwarunkowane socjologicznie nawrócenia poszczególnych badaczy okazują się ważniejsze od eksplanatywnych czy heurystycznych wartości porównywanych teorii. Socjologiczne teorie rewolucji naukowych są wynikiem silnej wiary w trwałość mechanizmów społecznych. W ich ujęciu te właśnie mechanizmy mają decydujący wpływ na przebieg rewolucji. Z upływem czasu ulegają zmianie koncepcje racjonalności, zasady metodologii, treść tych samych pojęć, tylko najogólniejsze prawidłowości rządzące społecznością uczonych mają po-

3 Przez elitystyczną teorię (elitist theory) rozwoju nauki rozumiem za I. Lakatosem teorię według której w przełomowych okresach rozwoju nauki decydującą rolę odgrywają ośrodki badawcze dysponujące dużym autorytetem. Dzięki prestiżowi tych ośrodków uznaje się podstawowe zasady nowych teorii, które nie posiadają w danym okresie abiektywnego uzasadnienia. Klasycznym przykładem teorii elitystycznej jest koncepcja przedstawiona przez T. Kuhna w The Structure of Scientific Revolution, Chicago 1962. 
zostawać niezmienne, decydując o identyczności najbardziej podstawowych struktur rewolucji naukowych.

Ta wiara w wyższość praw socjologii nad logiką nauki jest interesującym epistemologicznie przejawem fascynacji naukami społecznymi. Fascynacja ta jest przejawem optymizmu poznawczego już choćby tylko $\mathrm{z}$ tej racji, że prawa socjologii posiadające charakter statystyczny podnosi się $\mathrm{w}$ proponowanych teoriach rewolucji naukowych do rangi czynników determinujących jednoznacznie przebieg rewolucji. Niektóre z wyrafinowanych wersji tych teorii mogą okazać się niepodatne na falsyfikację. Jeśli ktoś z elitystycznych interpretatorów zechciałby argumentować np. iż twierdzenie Gödla o niezupełności systemów było przejawem kompleksów u Gödla, który musiał znać psychoanalityczną teorię kompleksów, gdyż mieszkał w tym samym Wiedniu co S. Freud, interpretacja taka byłaby niefalsyfikowalna. Równocześnie jednak byłaby ona calkowicie nieistotna dla logicznych ocen twierdzenia Gödla, gdyż uwarunkowania psychologiczne określać mogą co najwyżej kontekst odkrycia, lecz nie kontekst uzasadnienia. Psychologiczne uprzedzenia $\mathrm{w}$ stosunku do implikacji twierdzenia Gödla mogły inspirować różne formy krytycyzmu tego twierdzenia, ale dla logiki interesujący był jedynie ten krytycyzm, który wynikał dedukcyjnie z uzasadnionych przesłanek.

Analogiczna sytuacja zachodzi w okresie rewolucji naukowych. Czynniki psycho-społeczne mogą wówczas opóźniać recepcję pewnych idei, bezpodstawnie propagować inne, ale przypisywanie im decydującego wpływu na przebieg rewolucji jest przejawem irracjonalnej wiary w potęgę socjologii. Kiedy obserwuje się przejście od fizyki Newtonowskiej do Einsteinowskiej trudno przypuścić, by jakiekolwiek czynniki socjologiczne byly w stanie zdeterminować społeczność uczonych początku XX wieku do zlekceważenia wewnętrznej logiki rozwoju nauki i przyjęcia np. fizyki starożytnego Egiptu na miejsce teorii względności. Podobnie trudno wyobrazić sobie, by skutkiem jakichkolwiek uwarunkowań biologowie, nie zaś samozwańczy propagatorzy prywatnej biologii, zdecydowali się przyjąć obecnie biologię Łysenki połączoną z geologią Velikovskiego.

W stosunku do wielu wariantów elitystycznych teorii rewolucji naukowych możliwe jest określenie falsyfikujących kontrprzykładów. Jeśli bowiem np. w teorii takiej obok tezy o elitarnym uwarunkowaniu rewolucji przyjmuje się teze głosząca, iż w nowym paradygmacie korespondujące wyjaśnienia są niewspółmierne w stosunku do wyjaśnień starego paradygmatu, to nie można uniknąc kwestii, czy powszechna zgoda społeczności naukowych nie mogłaby doprowadzić do przyjęcia paradygmatu, w którym tylko część interpretacji byłaby niewspółmierna z klasycznymi, część zaś byłaby identyczna. Rozszerzając tę procedurę można by 
pytać, czy w wyniku zgody uczonych mogłyby zostać przyjęte w okresie rewolucji teorie niezgodne $\mathrm{z}$ teoriami postulowanymi przez określoną teorię rewolucji naukowych. W ten sposób albo trzeba byłoby zrezygnować z tezy o prymacie czynników socjologicznych, albo z poszczególnych wariantów socjologicznych teorii rewolucji naukowych.

Znacznie bardziej złożona jest ocena teorii rewolucji, w których decydujący czynnik kierujący rozwojem nauki ma stanowić jej wewnętrzna racjonalność. Istotny zarzut przeciw próbom wypracowania jednego algorytmu rozwoju nauki obowiązującego podczas wszystkich rewolucji dotyczy kwestii, czy koncepcja taka nie jest przejawem neo-heglowskiego racjonalizmu w filozofii nauki. Przejęty wiarą w racjonalność nauki Hegel dowodził apriorycznie, iż między Marsem a Jowiszem nie istnieją żadne obiekty podobne do planet, wówczas kiedy obserwacyjnie stwierdzono już istnienie w tym właśnie obszarze planetoidy Ceres. Neo-heglowska próba ekstrapolacji jednej teorii na wszystkie rewolucje naukowe albo będzie zbiorem ogólników określających prawidłowości, które implikowane są już w pojęciu rewolucji, albo też będzie próbą nie liczących się z faktami spekulacji, których falsyfikację utrudnia niedokładna znajomość faktów dotyczących dawnych rewolucji naukowych.

Anty-heglowski krytycyzm w dziedzinie filozofii nauki może być uznany za oznakę minimalizmu interpretacyjnego, gdyż pomija on fakt, iż cały rozwój nauki jest następstwem możliwości podporządkowania jednostkowych zdarzeń ogólnym prawom. Należy jednak zwrócić uwagę, że inny jest status tych praw na terenie nauk przyrodniczych, zaś inny $\mathrm{w}$ historii nauki. Wiara $\mathrm{w}$ jeden mechanizm kierujący rozwojem nauki niezależnie od czasu jest tak samo optymistyczna i tak samo nieuzasadniona, jak wiara w możliwość wypracowania jednej uniwersalnej teorii rewolucji proletariackiej obowiązującej w każdym kraju. Wewnętrzna racjonalność nauki jest możliwa do pogodzenia $\mathrm{z}$ wieloma wariantami rozwoju nauki w momentach przełomowych. Przejście od fizyki Newtonowskiej do fizyki relatywistycznej mogło przebiegać według innego schematu. Mogły być z nim związane długie stadia pośrednie, mogły powstać bardziej złożone niż Einsteinowska teorie, np. uwzględniające rolę spinu czy skręcania, albo też po okresie rozwoju mechaniki kwantowej mogła zamiast ogólnej teorii względności zostać wypracowana np. teoria Salama-Weinberga. Wobec wielorakich możliwości racjonalnego rozwoju próba określania jedynego mechanizmu rewolucji naukowych wydaje mi się pozostałością idei racjonalizmu redukcjonistycznego. W początkowym stadium rozwoju wiedzy idee te inspirowały metafizyczne programy badań prowadzące do prób tłumaczenia całej złożoności struktury świata przez odwołanie się do jednego lub kilku elementów podstawowych pełniących funkcje arche. Po powstaniu nauki nowożytnej racjonalizm redukcjonis- 
tyczny usiłowano wprowadzić na płaszczyznę poznania przyrodniczego dążąc do wyjaśnienia wszystkich procesów w kategoriach mechaniki. Po upadku mechanicyzmu idee te usiłowano wykorzystać na poziomie refleksji metanaukowej. W niektórych metanaukowych programach badań rozwiniętych $\mathrm{w}$ naszym stuleciu można odnaleźć metanaukowe warianty demona Laplace'a. Podczas gdy w okresie triumfów mechaniki sądzono, że demon ten mógłby przewidzieć wszystkie stany wszechświata dysponując znajomością warunków początkowych i praw ewolucji układu, w metanaukowym redukcjonizmie naszego stulecia usiłuje się $\mathrm{w}$ podobny sposób określać jednoznacznie przebieg rozwoju nauki na podstawie znajomości jej aktualnego stanu oraz nieuchronnych mechanizmów określających kierunek jej ewolucji. Demonizujący racjonalizm okazał się ostatecznie, podobnie jak XIX-wieczny redukcjonizm mechanistyczny, stanowiskiem zbyt optymistycznym i niemożliwym do utrzymania. Resztki tego opłymizmu ocalały do dziś w tezie uznającej możliwość wypracowania jednej teorii tłumaczącej naturę wszystkich rewolucji naukowych. Przy podobnych generalizacjach trudno jest uniknąc zarzutu petitionis principii. Nieuchronnie nasuwa się bowiem kwestia, na jakiej podstawie można ekstrapolować na wszystkie przełomowe sytuacje w rozwoju nauki prawidłowości zaobserwowane w ciągu kilku ostatnich stuleci? Czy ekstrapolacja taka nie jest przejawem podtrzymywania wierzeń w metanaukowego demona Laplace'a? Nie ma żadnych obiektywnych podstaw, by optymistycznie przypuszczać, że skomplikowany proces rozwoju nauki można przedstawić przy pomocy niewyszukanego modelu prostej, sinusoidy czy hiperboli zbliżającej się nieuchronnie do asymptoty. Jeśli nauka rozwija się nieliniowo w sposób, którego nie można zobrazować przy pomocy prostych modeli, nasze dążenie do jednolitej teorii wszystkich rewolucji naukowych jest dążeniem równie utopijnym co podejmowane $\mathrm{w}$ latach trzydziestych wysiłki do stworzenia zjednoczonej nauki. Wiele danych przemawia za takim właśnie nieliniowym rozwojem nauki. Znamienną cechą fizyki relatywistycznej jest to, iż w formalizmie teorii naukowych można znaleźć określone granice stosowalności tych teorii. Teorii Einsteina nie można więc stosować do gęstości większych niż $10^{93} \mathrm{~g} / \mathrm{m}^{3}$. W mechanice kwantowej nie można mówić o odległościach mniejszych od $10^{-33} \mathrm{~cm}$. Same teorie zawierają już ukryte określenie granic ich stosowalności, które to cechy nie występowały w teoriach naukowych wcześniejszego okresu. Podobna sytuacja zachodzi w naukach formalnych, gdzie twierdzenia limitacyjne ukazują granice dyskursu logicznego. Wyraźne określenie takich ograniczeń radykalnie zmienia status tzw. anomalii, których rola akcentowana jest we wszystkich teoriach rewolucji naukowej. Fakt, iż stosowanie równań Einsteina do opisu supergęstych stanów wszechświata prowadzi do pojawiania się nieskończonej gęstości czy tem- 
peratury, nie stanowi anomalii we właściwym sensie tego terminu, lecz tylko oznacza, iż teoria została odniesiona do niewłaściwej dziedziny i że trzeba poszukiwać nowej teorii opisującej procesy blisko osobliwości. Wypracowanie takiej teorii stanowiłoby niewątpliwie rewolucję $\mathrm{w}$ fizyce, gdyż połączone zostałyby dwie rozłączne dotychczas dziedziny: kosmologia i teoria kwantów. Nie widać jednak żadnego powodu, by apriorycznie postulować, iż do uznania nowej zjednoczonej teorii konieczny byłby np. efekt konwersji ${ }^{4}$. Trwające od lat prace nad stworzeniem kosmologii kwantowej dostarczyły wielu racjonalnych przesłanek do oceny poszukiwanej nowej teorii. Wyrazem dogmatycznego socjologizmu byłoby więc oczekiwanie, iż o recepcji tej teorii zadecydują przede wszystkim irracjonalne czynniki o charakterze autorytarno-psychologicznym.

Przedstawiona krytyka dążeń do wypracowania uniwersalnej teorii rewolucji naukowych nie implikuje kwestionowania wartości racjonalnych rekonstrukcji konkretnych rewolucji czy analiz porównawczych określających korelację między kolejnymi rewolucjami. W krytyce tej kwestionuję jedynie zasadniczą możliwość przedstawienia modelu rewolucji, który, nie będąc banalny informacyjnie z powodu ogólnikowych sformułowań, mógłby być uważany za adekwatny model wszystkich rewolucji naukowych. Niemożność wypracowania takiego modelu ma charakter zasadniczy, gdyż skomplikowanego procesu rozwoju nauki nie można podporządkować jednemu zbiorowi niebanalnych algorytmów. $\mathrm{Z}$ analiz ewolucji układów wypracowanych w teorii katastrof René Thoma wynika, jak ścisłe są korelacje między przebiegiem ewolucji a liczbą czynników determinujących rozwój układu. Teoria ta ukazuje siedem zasadniczych typów nieciągłej ewolucji systemów, których rozwój uzależniony jest od nie więcej niż czterech czynników determinujących. Przy niewielkim wzroście liczby tych czynników następuje wysoki wzrost liczby możliwych wariantów ewolucji i beznadziejne stają się próby bliższego określenia kierunku zmian w badanym systemie. W tym kontekście dążenie do wypracowania jednego niebanalnego modelu rewolucji naukowych jest wyrazem optymizmu poznawczego znacznie większego niż ten, który w średniowieczu prowadził do twierdzeń: Simplicitas est sigillum veri czy Natura simplicitatem amat.

Czynnikiem inspirującym dążenie do jednej uniwersalnej teorii rewolucji było przekonanie, iż $\mathrm{w}$ przełomowych punktach rozwoju nauki decydującą rolę odgrywa jeden typ uwarunkowania, bądź to racjonalnych bądź socjologicznych, zaś rolę pozostałych czynników można lokalnie

${ }^{4}$ Według T. Kuhna przyjęcie podstawowych założeń nowego paradygmatu dokonuje się nie w wyniku ich obiektywnych uzasadnień, lecz w następstwie aktów nawrócenia (conversion effect) poszczególnych badczy porzucających interpretacyjne wzorce starego paradygmatu. 
sprowadzić do zera. Przekonanie to było niewątpliwie wyrazem optymizmu metanaukowego. Problem jednak w tym, że rzeczywisty rozwój nauki nie zawsze chce się stosować do optymistycznych zaleceń.

\section{II}

W konflikcie między racjonalistyczną koncepcją rozwoju nauki, rozwijaną w kręgach zwolenników Poppera, a koncepcją socjologiczno-elitarną inspirowaną przez T. Kuhna decydującą rolę odgrywa rozróżnienie między kontekstem odkrycia i kontekstem uzasadnienia. Wśród autorów akcentujących rolę racjonalnych składowych nauki jej rozwój charakteryzowany jest przez odwołanie się do wewnętrznych czynników składowych konstytuujących kontekst uzasadnienia. Prowadzi to do internalistycznych koncepcji, w których zrelatywizowane historyeznie społeczno-psychologicznie uwarunkowania rozwoju nauki mogą być interesujące, lecz mimo to są nieistotne. Wśród zwolenników elityzmu metanaukowego szczególnie doniosłe funkcje są przypisywane kontekstowi odkrycia. W ujęciu tym oceny racjonalności poszczególnych teorii, ich statusu empirycznego, walorów eksplanatywnych, etc. są uwarunkowane czasowo i środowiskowo. Czynnikiem decydującym jest opinia kompetentnych przedstawicieli środowisk naukowych, w której to opinii oceny uwarunkowane psycho-społecznie dominują nad ocenami dającymi się uzasadnić $\mathrm{w}$ sposób logicznie niekwestionowalny. Stanowisko elityzmu, poprzez eksternalistyczną wizję nauki determinowaną przez zewnętrzne czynniki pozalogiczne, bliskie jest zarówno socjologizmowi Kuhna, teorii „milczącej wiedzy" Polanyia, jak i ujęciom pragmatyzmu czy marksistów akcentujących historyczno-społeczne uwarunkowania nauki. Tę koncepcję elity, określającej kierunki rozwoju wiedzy, z sarkazmem krytykuje I. Lakatos, pisząc: „W obrębie naukowej elity istnieje struktura autorytetów. Najwyżsi sędziowie są wybierani (albo „wyłaniają się”); siadają w swych lożach i wydają wyroki zależnie od poszczególnych przypadków. Żadne ogólne prawo (czy jakieś ,kryterium demarkacji”) nie ogranicza ich potęgi. Co jednak dzieje się wtedy gdy członkowie Sądu Najwyższego nie zgadzają się między sobą? (...) Większość zwolenników elityzmu woli odpowiedź: wszelkie konflikty wewnątrz elity rozwiązuje się za pośrednictwem przetrwania jednostek najbardziej dostosowanych do walki o byt. Dokąd wśród elity brakuje zgody, ci którzy do niej nie należą powinni z należną czcią obserwować walkę gigantów, następnie zaś przyjąć zwycięzcę jako zwiastuna postępu" ${ }^{5}$.

5 I. Lakatos, The Problem of Appraising Scientific Theories, w: Philosophical Papers, t. 2, ed. J. Worall, G. Currie, Cambridge 1980, $116 \mathrm{n}$. 
Niemniej groteskowe opisy można kierować przeciw internalistycznym teoriom rozwoju nauki odwołującym się jedynie do elementów kontekstu uzasadnienia. Ukazywana w nich neo-Darwinowska wizja, w której czynnikiem decydującym o zwycięstwie poszczególnych teorii w walce o byt są wyłącznie ich walory informacyjne, jest równie optymistyczna, co nierealna. W realistycznych teoriach rozwoju idei naukowych należy traktować naukę jako wypadkową elementów racjonalno-empirycznych oraz zewnętrznych uwarunkowań społeczno-kulturowych. Te ostatnie sprawiają, iż w naukowych programach badawczych podtrzymywane sa twierdzenia czy procedury, których status teoretyczny albo jest niejasny, albo prowadzi do sprzeczności z innymi uznanymi wcześniej twierdzeniami. Do tego typu procedur należą współcześnie np. techniki renormalizacyjne w elektrodynamice kwantowej. Eliminują one efektywnie wielkości nieskończone $\mathrm{z}$ formalizmu teorii, mimo braku uzasadnionych teoretycznie podstaw takiej eliminacji. Na gruncie fizyki Newtonowskiej trudności z perihelium Merkurego czy paradoksem Olbersa prowadziły do pytań, na które nie można było udzielić poprawnej logicznie i zgodnej $\mathrm{z}$ ówczesnym paradygmatem odpowiedzi. Logiczny komponent obu wspomnianych teorii uzyskiwał jednak uzupełnienie $\mathrm{w}$ postaci psychologicznego zaufania i społecznej akceptacji rozwiązań obciążonych trudnościami teoretycznymi czy obserwacyjnymi.

Zewnętrznego czynnika psycho-społecznego nie można pomijać w historiografii nauki, jeśli chce się uniknąć uproszczeń naiwnego dedukcjonizmu. Nieporozumieniem byłoby jednak również podnoszenie tego czynnika do roli decydującej determinanty rozwoju idei naukowych. Wewnętrzna logika rozwoju podstawowych idei konstytuujących naukę pozostaje transcendentna w stosunku do uwarunkowań spoleczno-kulturowych. Prawo Archimedesa czy twierdzenie Pitagorasa zawierają treści, których nie są w stanie zakwestionować żadne uwarunkowania społeczne. Próby klasowego podejścia do mechaniki kwantowej czy wypracowania proletariackiego odpowiednika teorii względności nie należą do historii nauki, lecz do historii patologii myślenia. Sformułowanie zasady nieokreśloności Heisenberga było taką samą logiczną konsekwencją wyprowadzoną z podstawowych założeń mechaniki kwantowej, jak Hawkingowska zasada przypadkowości jest konsekwencją logiczną zastosowania praw mechaniki kwantowej do czarnych dziur. Społeczno-psychologiczny kontekst odkrycia może w ostatnim z wymienionych przykładów odgrywać ważną rolę przez to, że w panującej obecnie atmosferze intelektualnej ocenia się pozytywnie wszelkie prace z zakresu fizyki czarnych dziur, podczas gdy 50 lat wcześniej prace takie krytykowano jako absurdalne i niepoważne. Ta zmiana klimatu nie dowodzi jednak, by w wyniku uwarunkowań społecznych zmieniły się obiektywne kryteria racjonalności 
czy wskaźniki absurdu w fizyce teoretycznej. Zmianie uległy jedynie społeczne opinie dotyczące tej racjonalności. Wewnętrzna racjonalność równań opisujących tzw. promień Schwarzschilda czarnej dziury jest w obecnych pracach poświęcanych tej tematyce identyczna jak w słynnym tekście P. S. Laplace'a, w którym już w 1795 r. dopuszczano możliwość istnienia tych obiektów rażąco sprzecznych $\mathrm{z}$ podstawowymi zasadami zdrowego rozsądku. Wewnętrznej racjonalności rozwoju mechaniki Newtona nie można zredukować do żadnego zespołu uwarunkowań psycho-spolecznych, gdyż podstawowe zasady logiki, którą posługujemy się przy rozwijaniu teorii naukowych nie są rezultatem umowy społecznej, lecz czynnikiem niezależnym od przeobrażeń społecznych.

Zbyt optymistyczny byłby obraz rozwoju nauki, w którym uczeni dysponujący znajomością wewnętrznej logiki nauki rozwijaliby swe teorie niezależnie od pozanaukowych uwarunkowań. Obraz nauki jako ciągu racjonalnych idei można otrzymać jedynie ex post $\mathrm{w}$ rekonstrukcjach historiograficznych, natomiast realny proces uprawiania nauki dokonuje się na sposób sygnalizowany przez A. Koestlera już w tytule jego Sleepwalkers. W procesie tym nierzadko uwarunkowane kulturowo czy historycznie mity podnoszone są do rangi racjonalnych zasad, zaś wyidealizowane hic et nunc reguły traktowane sa jako podstawowe kryteria oceny (cfr. weryfikowalność w okresie międzywojennym). Dlatego też dopiero w przeprowadzonych ex post ocenach możliwe jest jednoznaczne oddzielenie elementów kontekstu odkrycia od elementów kontekstu uzasadnienia. Nierzadko czynniki, które w początkowych stadiach rozwoju teorii uważane są za elementy kontekstu uzasadnienia okazują się potem składnikami kontekstu pseudo-uzasadnienia ${ }^{6}$. W mej opinii w procesie rozwoju idei naukowych decydującej roli nie należy przypisywać ani samym czynnikom konstytuującym kontekst odkrycia, ani samym elementom kontekstu uzasadnienia, lecz wypadkowej tych dwóch czynników tworzących całość, którą określam mianem k on teks t u a k ceptacji.

Kontekst akceptacji składa się z zespołu tych czynników, które sprawiaja, iż określony program badawczy zyskuje aprobatę $\mathrm{w}$ danym okresie rozwoju nauki i zostaje uznany za prawomocną interpretację rzeczywistości. Podstawowym czynnikem decydującym o tej prawomocności są walory teoretyczne lub konfirmacje empiryczne proponowanego programu. Nierzadko jednak walorów takich albo brak, albo ich stwierdzenie wymaga uznania innych kontrowersyjnych teorii. W sytuacji takiej decydującą rolę w kontekście akceptacji odgrywają czynniki psycho-społecz-

${ }^{6}$ Było tak np. z podawanymi przez Galileusza argumentami za ruchem Ziemi odwołującymi się do przypływów, czy uzasadnianiem teorii stanu stałego przez odwołane do ,faktu”, iż wiek Ziemi jest wyższy od wieku obiektów kosmicznych naszego sąsiedztwa. 
ne, których obecność pozwala unikać hamletyzmu przy ocenie teorii o fundamentalnym znaczeniu. Sytuacja taka miała miejsce np. przy ocenie astronomii Galileusza przed powstaniem fizyki Newtonowskiej. Kontrpropozycją w stosunku do systemu Galileusza był $\mathrm{m}$. in. system Tychona Brahe zaś najważniejsze obserwacje potwierdzające słuszność astronomii Galileusza uzyskano dopiero w 1838 r. po odkryciu paralaksy przez F. W. Bessela. To że astronomię tę przyjęto znacznie wcześniej, uzależnione było w dużym stopniu od psychospołecznych elementów kontekstu akceptacji. Uzależnione były one od intelektualnego klimatu sprzyjającego krytycyzmowi wobec autorytetów oraz od rozwoju licznych prób wprowadzania nowych obrazoburczych interpretacji. Jak podkreśla P. Feyerabend, wśród uwarunkowań nowej astronomii i nowej fizyki znalazła się optymistyczna teza iż obok nowo odkrytej Ameryki może znajdować się jeszcze nieznana Ameryka ludzkiej wiedzy - kontynent, którego odkrycia nie dokona się drogą prostej dedukcji, gdyż wymaga ono odwagi interpretacyjnej podobnej do odwagi K. Kolumba ?

To współistnienie elementów racjonalnych i pozaracjonalnych $\mathrm{w}$ kontekście akceptacji odsłania bezpodstawność prób wypracowania jednej uniwersalnej teorii rewolucji naukowych. Ponieważ nie istnieje żadna ogólna zasada określająca stałą relację między czynnikami racjonalnymi i społeczno-kulturowymi, czynniki te mogą odgrywać różnorakie role w różnych etapach rozwoju nauki. Można dopuścić możliwość, iż akceptacja jakiegoś radykalnie nowego programu badawczego dokona się w sposób zgodny z T. Kuhna teorią rewolucji naukowych, podobnie jak można dopuścić możliwość, że któraś z rewolucji społecznych będzie miała przebieg zgodny z teorią rewolucji K. Marksa. Próba podporządkowania kontekstu akceptacji uniwersalnemu zbiorowi jednoznacznych reguł byłaby jednak wyrazem nie liczącego się z realiami totalitaryzmu metodologicznego. Interpretacyjną kontrpropozycję w stosunku do niego stanowi anarchistyczna teoria rewolucji naukowych, w której w poszczególnych rewolucjach występują zróżnicowane prawidłowości.

Koncepcja ta niszczy wprawdzie ład i piękno zunifikowanych teorii rewolucji ukazujących przejrzystą wizję rozwoju nauki podporządkowanej jednemu zespołowi determinant. Nie zawsze jednak unifikacja i przejrzystość są oznaką teoretycznego rozwoju wiedzy; niekiedy są one jedynie produktem quasi-naukowej mitologii. We wczesnych stadiach rozwoju geografii przyjmowano, iż Europa jest ostro oddzielona od Azji przez rzekę Phasis, zaś Pad, Ren i Rodan stanowią jedynie odgałęzienia Eridanosu ${ }^{8}$. Traktowanie poszczególnych rewolucji naukowych jako prze-

7 Por. P. K. Fe yerabend, Science in a Free Society, London 1978.

8 Zab. A. G. Is a czenk o, Rozwój myśli geograficznej, Warszawa 1975, 35 n. 
jawów metanaukowego Eridanosu może łatwo prowadzić do nowej mitologii, w stosunku do której alternatywą jest anarchistyczna teoria rewolucji naukowych.

\section{AN ANARCHISTIC THEORY OF SCIENTIFIC REVOLUTIONS}

\section{S u m m a r y}

The recent attempts at formulating an universal theory of scientific revolutions strive at disclosing the mechanisms governing all shifts of scientific paradigms. Two basically different types of interpretations may be distinguished among them. In the first approach the laws of revolutions are described in the sociology of science; in the second - the laws are claimed to be a result of an internal rationality of science. The paper contains critical comments on both these interpretations and proposes an anarchistic theory of revolutions as a counterproposal, in which particular scientific revolutions are directed by different laws depending on complex relationships between external (sociological) and internal (rational-empirical) conditioning of the growth of science. There is no objective foundation for optimistic believing that the complicated process of the evolution of science could be represented by one plainmodel; on the contrary, there are many reasons to accept a complex alinear evolution of scientific knowledge.

From the analysis of the evolution of systems developed in René Thom's theory of catastrophes one sees how strict are the relationships between the course of the evolution and the number of factors determining the growth of systems. If the evolution of a system governed by a potential is determined by no more than four different factors, there are seven structurally stable possibilities of discontinuous evolution of the system. A growth of the number of determining factors is followed by a rapid increase of the number of possible variants of evolution. In this context, any attempt at developing a unique non-trivial model of scientific revolutions expresses epistemological optimism stronger than that which in the medieval times led to the search of the philosophers' stone. A neo-Hegelian rationalist attempt at extending a single metascientific theory to cover all scientific revolutions will yield either a set of generalites describing merely the phenomena implied in the very concept of a revolution, or an attempt at fact-disregarding speculation unverifiable because of the lack of exact data concerning pasit scientific revolutions.

It is significant that in the course of the metascientific revolution which took place within our century, the revolution in metamathematics took a completely different course than the revolution in the epistemology of natural sciences. Breakthrough discoveries in mathematics had not been preceded by an increase in the number of anomalies but followed the attempts at defining the foundations of mathematics. Moreover, no claim could be made that this revolution led to incommensurable changes in the basic concepts of the integer or set, though certain terms (e.g. the infinitesimals in non-standard analysis) changed their meaning.

The attempt to formulate an universal theory of scientific revolutions on the basis of known facts concerning the Galileo-Newton and Einstein -Planck revo- 
lutions would be just as risky an underakting as to try to develop a theory of society on the basis of observations of two pensioners. Such attempts raise questions of representative ample, criteria of generalizations, principles for distinguishing essential from non-essential factors. For this reason all proposed theories of scientific revolutions are merely conjectural, whereas the belief in a single universal theory may be upheld only in highly idealized approaches where simplicity becomes more important than adequacy. 